\title{
接続マトリックスを用いた骨組構造の最適設計 APPLICATION OF CONNECTION MATRIX TO OPTIMUM DESIGN OF FRAMED STRUCTURES
}

\author{
小 林 一 郎*.吉 本 俊 裕** - 三 池 亮 次*** \\ By Ichiro KOBAYASHI, Toshihiro YOSHIMOTO and Ryoji MIIKE
}

\section{1. はじめに}

最適設計研究の初期の段階においては，たとえば， $\mathrm{Schmit}^{1}{ }^{1}$ の 3 部材トラスのような簡単な構造をモデルと し, しかも部材断面特性としては, 単に部材断面積 $A$ の みを設計変数とすることが多かったが,近年,示方書に準 拠したより実用的な部材断面を用いる傾向がある2) 5).

より実用的で大規模かつ複雑な構造物の最適設計問題 に関心が移行するに従って, 設計变数と制約条件式の数 が膨大なものとなり，計算機の容量の制約と計算精度と 効率の向上を図るためにSuboptimization の研究(7 9)や， 小山・長吕のように，変数変換により制約条件式を整理 したり，余裕ある制約条件式を除く解法が試みられた.

構造物の部材断面 (sizing) の最適設計だけでなく, 最適形状 (optimal configuration, geometry) を自動的 に得ようとする研究もまた, 最適設計における重要課題 の 1 つである ${ }^{10), 11), 14) . ~}$

Pederson ${ }^{12)}$ は， 部材断面積と節点座標を設計変数と し，直接剛性法を用いた SLP 法に従って，立体トラス の最適形状を得ており, $\mathrm{Saka}^{13)}$ は，変位 $\boldsymbol{d}$ と外力 $\boldsymbol{p}$ の 関係式を付帯条件式として，変位 $\boldsymbol{d}$ を設計変数に加え て解析している. わが国では, 節点を設計変数とするピ ン結合トラスの最適設計の定式化について, 中村 ${ }^{15)}$, 大 久保 ${ }^{4}$ の, 剛結合部材も含めた構造について古田 ${ }^{16)}$ の研 究がある。

外力と部材端力を結びつけるマトリックス $\boldsymbol{C}$ は, 一般 に incidence matrix ${ }^{2,16)}$ とよばれるが, 同様のものを, Romstad と Wang ${ }^{17)}$ は statics matrix, Livesley ${ }^{18)}$ は

\footnotetext{
* 正会員 工修 熊本大学助手 工学部土木工学科

** 正会員 工修 建設省九州地方建設局 (元熊本大学工学部 大学院工学研究科)

*** 正会員 工博 熊本大学教授 工学部土木工学科
}

接続マトリックス (connection matrix) と称した.

接続マトリックス $\boldsymbol{C}$ を用いると, 外力 $\boldsymbol{p}$ と部材断面力 $\boldsymbol{p}_{m}$ とが陽形式で結びつけられるので直接剛性法に比べ ると 1 次導関数すなわち感度係数の算出が容易となる.

ここでは，(1) 接続マトリックス $\boldsymbol{C}$ が部材端における いわゆる座標変換マトリックス $\boldsymbol{T}$ と平衡マトリックス $\boldsymbol{H}$ によって構成されるため, 接続マトリックス $\boldsymbol{C}$ の設 計変数による感度係数は, 結局, $\boldsymbol{T}$ と $\boldsymbol{H}$ の感度係数の 問題に帰着することを明らかにし，したがって，(2) 接続 マトリックスを用いることによって, 剛結骨組構造にお ける座標を設計変数とする最適形状設計の定式化が組織

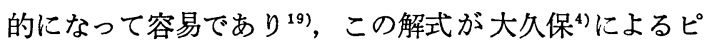
ン結合トラスの最適形状設計の基礎式を一般化したもの であることを示す. また，(3) 接続マトリックスは，部 材断面力の影響線を与えるマトリックスであり, これを 用いることによって最大の部材断面力を生ぜしめるよう な荷重配置を考虑した，より現実的な荷重条件のもとで の最適設計が可能となることを明らかにする に, (4) (3)の解析においては, より実用的な箱型断面の ピン結合トラスを例題とするが, 断面の特性值として, ウェブとフランジの板厚 $t_{w}, t_{f}$ と部材幅 $b$, 部材高 $h$ の 4 つの変数の代わりに, これを断面積 $A$, 細長比 $\lambda$, 部 材幅 $b$ および断面の形状係数 $C_{F}$ （または, 部材高 $h$ ) の 4 つの独立な設計変数に変換して用いる. 制約条件式 として, 道路橋示方書 ${ }^{22}$ に示される板厚の制限, 面外座 屈防止の条件も考虑し, より現実的な最適断面が得られ ることを示す. なお, 最適化手法としては, 反復線形計 画法（SLP）を用いる.

\section{2. 接続マトリックスを用いた骨組形状の最適 設計}

構造物の最適設計のアルゴリズムが正確かつ円滑に実 
行されるためには，構造解析の基礎式が適切でなければ ならない．しかるに直接剛性法を用いた基礎式による方 法では，一般に，局所座標系に基づいて作成された応力 の制約条件式と全体座標系に基つく構造全体の剛性マト リックスの関連が Taylor 展開して線形化することも手 伝って非常に繁雑となる.

Livesley $^{18)}$ のいうように，接続マトリックスは，座標 変換マトリックスと平衡マトリックスによって組み立て られている. われわれは，このことに着目して，接続マ トリックスを用いると，最適設計における感度係数の誘 導がより簡潔にかつ組織的に行えること,したがって,剛 結骨組構造物の座標を設計変数としたり，移動荷重に対 して最大断面力を与える荷重配置を考慮した最適設計の 定式化が比較的容易となることをさきに指摘した ${ }^{199,20)}$. また，接続マトリックスを用いると剛結合やピン結合が 混在する節点をもった構造の最適設計も容易に解析する ことができる.

記号の説明をかねて以下に構造解析の基䂾式を示す. 外力 $\boldsymbol{p}$, 部材端力 $\boldsymbol{p}_{m}$, 節点変位 $\boldsymbol{d}$, 接続マトリックス $C$, 剛性マトリックス $K_{m}$ 注1) とすると

$$
\begin{aligned}
& \boldsymbol{p}=\boldsymbol{C} \boldsymbol{p}_{m} \\
& \boldsymbol{d}=\left(\boldsymbol{C} \boldsymbol{K}_{m} \boldsymbol{C}^{T}\right)^{-1} \boldsymbol{p}=\boldsymbol{G}^{-1} \boldsymbol{p} \\
& \boldsymbol{p}_{m}=\boldsymbol{K} \boldsymbol{C}^{T} \boldsymbol{d} \ldots \ldots \ldots \ldots
\end{aligned}
$$

となる. 接続マトリックス $\boldsymbol{C}$ は, 座標変換マトリックス $\boldsymbol{T}_{\boldsymbol{i}}$ と部材端 1 および 2 とおける断面力 $\boldsymbol{p}_{\boldsymbol{i} 1}$ と $\boldsymbol{p}_{\boldsymbol{i}_{2}}$ の関係 を規定する平衡マトリックス $\boldsymbol{H}_{i}$ 主2) と $\boldsymbol{T}_{\boldsymbol{i}}$ 主3) の積 $\boldsymbol{U}_{\boldsymbol{i}}=$ $\boldsymbol{T}_{i} \boldsymbol{H}_{\boldsymbol{i}}$ の $i=1,2, \cdots, k$ のすべての值の関数として与え られる。

\section{(1) 設計変数21)}

骨組鋼構造において，もっぱら用いられる箱型とか I 型の断面形状を示す設計変数は, 図一1 に示すとおり, 部材幅 $b$, 部材高 $h$ とそれぞれの板厚 $t_{f}, t_{w}$ の 4 個で あるが，板厚の代わりに断面積 $A$ と細長比 $\lambda$ を用い，独 立の設計変数を $A, \lambda, h, b$ の 4 個とする方が数式の展 開が容易となる. 部材高の代わりに, 断面 2 次半径を $r$ として, $C_{F}=h / 2 r$ という無次元パラメーターを用いる ことも可能である. 以下に断面形状に関する設計変数の

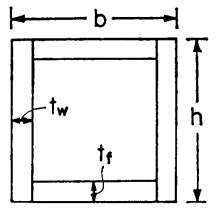

(a) 箱型断面

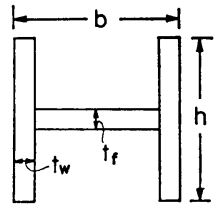

(b) I 型断面
図一1 断面形状

注 1) 補遺 (1) 参照

2) 補遺 (2) 参照

3) 補遺 (2) 参照
関係式を示す。

a) $\left(t_{f}, t_{w}, h, b\right)$ と $(A, \lambda, h, b)$ の関係式 [箱型断面]

$$
t_{f}=\frac{A(12 \beta-1)}{4 b}, t_{w}=\frac{3 A(1-4 \beta)}{4 h}, h=h, b=b
$$

[ I 型断面]

$$
t_{f}=\frac{A(1-12 \beta)}{b}, t_{w}=\frac{6 A \beta}{h}, h=h, b=b
$$

ただし, $\beta=\left(\frac{L}{\lambda h}\right)^{2}$

b) $\left(t_{f}, t_{w}, h, b\right)$ と $\left(A, \lambda, C_{F}, b\right)$ の関係式 [箱型断面]

$$
\left.\begin{array}{l}
t_{f}=\frac{A\left(3-C_{F}^{2}\right)}{4 b C_{F}^{2}}, t_{w}=\frac{3 A \lambda\left(C_{F}^{2}-1\right)}{8 C_{F}^{3} L} \\
h=\frac{2 C_{F} L}{\lambda}, b=b
\end{array}\right\}
$$

[ I 型断面]

$$
\begin{aligned}
& t_{f}=\frac{A\left(C_{F}{ }^{2}-3\right)}{b C_{F}{ }^{2}}, t_{w}=\frac{3 A \lambda}{4 C_{F}{ }^{3} L} \\
& h=\frac{2 C_{F} L}{\lambda}, b=b
\end{aligned}
$$

ただし， $L$ は部材長である. 上記の 4 個の独立パラメー ター $A, \lambda, C_{F}, b$ を用いるとき, $i$ 部材の 剛性マトリ ックスは,

$$
\boldsymbol{K}_{i}=E_{i} A_{i}\left[\begin{array}{ccc}
\frac{1}{L} & 0 & 0 \\
0 & \frac{12}{L \lambda^{2}} & -\frac{6}{\lambda^{2}} \\
0 & -\frac{6}{\lambda^{2}} & \frac{4 L}{\lambda^{2}}
\end{array}\right] .
$$

である.ここに， $E_{i}$ は $i$ 部材の弾性係数である. また， 断面力 $\boldsymbol{p}_{m}$ より応力 $\sigma_{m}$ を求める式 $\sigma_{m}=D_{m} p_{m}$ 注4) に おける係数マトリックスは $i$ 部材について

$$
\boldsymbol{D}_{i}=\left[\frac{1}{A} \pm \frac{\xi h}{2 I} \pm \frac{h}{2 I}\right]_{i}=\left[\frac{1}{A} \pm \frac{\xi C_{F} \lambda}{A L} \pm \frac{C_{F} \lambda}{A L}\right]_{i}
$$

となる. ただし， $\xi=0$ または $L$ で，I は断面 2 次モー メントである.

\section{(2) 感度係数}

任意の設計変数 $X$ について, $\sigma_{m}$ と $p_{m}$ を微分すると

$$
\begin{aligned}
& \frac{\partial \boldsymbol{\sigma}_{m}}{\partial X}=\frac{\partial \boldsymbol{D}_{m}}{\partial X} \boldsymbol{p}_{m}+\boldsymbol{D}_{m} \frac{\partial \boldsymbol{p}_{m}}{\partial X} \cdots \cdots \cdots \cdots \cdots(10) \ldots \ldots \ldots \\
& \frac{\partial \boldsymbol{p}_{m}}{\partial X}=\frac{\partial \boldsymbol{K}_{m}}{\partial X} \boldsymbol{C}^{T} \boldsymbol{d}+\boldsymbol{K}_{m} \frac{\partial \boldsymbol{C}^{\boldsymbol{T}}}{\partial X} \boldsymbol{d}+\boldsymbol{K}_{m} \boldsymbol{C}^{\boldsymbol{T}} \frac{\partial \boldsymbol{d}}{\partial X}
\end{aligned}
$$

となる. 上式において $\boldsymbol{D}_{m}, \boldsymbol{K}_{m}, \boldsymbol{C}$ の感度係数が得ら れれば $\partial \sigma_{m} / \partial X$ が求められる. $\partial C / \partial X$ は, $\partial T_{i} / \partial X$ と

注 4) 補遺 (1) 参照 
$\partial \boldsymbol{H}_{\boldsymbol{i}} / \partial X$ が求まれば機械的に作成することができる．ま た $\boldsymbol{K}_{m}$ と $\boldsymbol{D}_{m}$ の感度係数は各部材のマトリックス $\boldsymbol{K}_{i}$ と $\boldsymbol{D}_{\boldsymbol{i}}$ の感度係数を求めればよい. したがって, $\boldsymbol{T}_{i}, \boldsymbol{H}_{\boldsymbol{i}}$, $K_{i}, D_{i}$ の導関数が計算されれば式 (10)，(11) の感度係 数は解析的に求められる. 以下にこれらの感度保数を示 す. ただし，添字 $j$ は節点 $j$ を表わす.

a）断面に関するパラメーターを設計変数にする場合 $\boldsymbol{T}_{i}$ と $\boldsymbol{H}_{i}$ は節点座標のみの関数であるので, 感度係 数はゼロである.

$$
\left.\begin{array}{l}
\frac{\partial \boldsymbol{D}_{i}}{\partial A_{i}}=\left[-\frac{1}{A^{2}} \mp \frac{\xi C_{F} \lambda}{A^{2} L} \mp \frac{C_{F} \lambda}{A^{2} L}\right]_{i}=-\frac{1}{A} \boldsymbol{D}_{i} \\
\frac{\partial \boldsymbol{D}_{i}}{\partial \lambda_{i}}=\left[0 \pm \frac{\xi C_{F}}{A L} \pm \frac{C_{F}}{A L}\right]_{i} \\
\frac{\partial \boldsymbol{D}_{i}}{\partial C_{F i}}=\left[0 \pm \frac{\xi \lambda}{A L} \pm \frac{\lambda}{A L}\right]_{i}, \frac{\partial \boldsymbol{D}_{i}}{\partial b}=\mathbf{0}
\end{array}\right\}
$$

$$
\left.\begin{array}{l}
\frac{\partial \boldsymbol{K}_{i}}{\partial A_{i}}=\frac{1}{A_{i}} \boldsymbol{K}_{i}, \frac{\partial \boldsymbol{K}_{i}}{\partial C_{F}}=\frac{\partial \boldsymbol{K}_{i}}{\partial b}=\mathbf{0} \\
\frac{\partial \boldsymbol{K}_{i}}{\partial \lambda_{i}}=\left[\begin{array}{ccc}
0 & 0 & 0 \\
0 & -\frac{24}{L \lambda^{3}} & \frac{12}{\lambda^{3}} \\
0 & \frac{12}{\lambda^{3}} & -\frac{8 L}{\lambda^{3}}
\end{array}\right]_{i}
\end{array}\right\}
$$

b）節点座標を設計変数とする場合

任意の節点座標を $x_{j}$ とする. また, $r_{i}=\cos \theta_{i}, \mu_{i}=$ $\sin \theta_{i}$ であり $\theta_{i}$ は $x$ 軸と部材軸のなす角である注5).

$$
\begin{aligned}
& \frac{\partial \boldsymbol{T}_{i}}{\partial x_{j}}=\left[\begin{array}{ccc}
\frac{\partial r}{\partial x_{j}} & -\frac{\partial \mu}{\partial x_{j}} & 0 \\
\frac{\partial \mu}{\partial x_{j}} & \frac{\partial r}{\partial x_{j}} & 0 \\
0 & 0 & 0
\end{array}\right]_{i} \\
& \frac{\partial \boldsymbol{H}_{i}}{\partial x_{j}}=\left[\begin{array}{ccc}
0 & 0 & 0 \\
0 & 0 & 0 \\
0 & \frac{\partial L}{\partial x_{j}} & 0
\end{array}\right]_{i} \\
& \frac{\partial \boldsymbol{D}_{i}}{\partial x_{j}}=\left[\begin{array}{lcc}
0 & \mp \frac{\xi C_{F} \lambda}{A L^{2}} \frac{\partial L}{\partial x_{j}} & \mp \frac{C_{F} \lambda}{A L^{2}} \frac{\partial L}{\partial x_{j}}
\end{array}\right]_{i} \\
& \frac{\partial \boldsymbol{K}_{i}}{\partial x_{j}}=-E_{i} A_{i}\left[\begin{array}{ccc}
\frac{1}{L^{2}} & 0 \\
0 & \frac{12}{\lambda^{2} L^{2}} & \frac{\partial L_{i}}{\partial x_{j}}
\end{array}\right.
\end{aligned}
$$

なお，ピン結合トラスの場合には，平衡マトリックス $\boldsymbol{H}_{i}=1$ であり, 座標変換マトリックス $\boldsymbol{T}_{i}=\left[\gamma_{i} \mu_{i}\right]^{T}$ と なるため接続マトリックスは, 座標変換マトリックスの みによって構成されることとなり，大久保( による座標 を設計変数とする最適形状設計の解式に一致することに なる.

注 5) 補遺 (3) 参照

\section{3. 影響線マトリックスを用いた最適設計 ${ }^{201}$}

\section{（1）影響線マトリックス}

接続マトリックス $\boldsymbol{C}$ は, 外力 $\boldsymbol{p}$ を部材断面力 $\boldsymbol{p}_{\boldsymbol{m}}$ に 変換する係数マトリックスで式 (1) によって与えられる が, 静定構造の場合は逆に

$$
p_{m}=C^{-1} p \equiv \Gamma p
$$

であり，不静定構造の場合は，式 (2)，(3) より

$$
\Gamma=K_{m} C^{T} G^{-1}
$$

となる. 上式で定義される $\boldsymbol{\Gamma}$ の要素は， 任意の節点に 単位の荷重が作用するときの部材断面力である.すなわ ち $\Gamma$ マトリックスは，その $i$ 行ベクトル $l_{i}{ }^{T}=\left[l_{i 1} l_{i 2}\right.$ $\left.\cdots l_{i m}\right]$ が, $i$ 部材の部材断面力の影響線の縦距を与える ことになる. 同様に式 (2) より $\boldsymbol{G}^{-1}$ は変位の影響線マ トリックスを与える.

この $l_{i}$ を使用して，等分布死荷重 $p_{d}$ と等分布活荷 重 $P_{l}$ および集中活荷重 $P_{l}$ が作用するときの最大部材 断面力を求める. 図一2 の影 響線図の正の面積の絶対値を $S_{+}$, 負の面積の絶対値を $S_{-}$, 両者のうちの大きい方の面積 を $S$ とする. また, $S_{+}>S_{-}$ のとき, 縦距の最大値を $l_{\max }$ とし $S_{-}>S_{+}$のときは， 縦 距の最小値を $l_{\max }$ とすると,

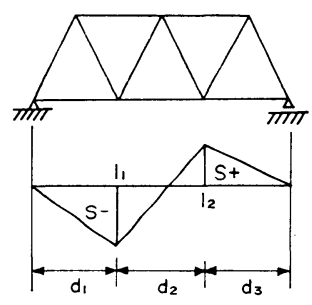

図一2 トラスの影帮線图 $i$ 部材の最大断面力 $p_{m, \max , i}$ は

$$
\begin{aligned}
& p_{m d}=\left(S_{+}-S_{-}\right) p_{d} \ldots \\
& p_{m l}=l_{\max } P_{l}+S p_{l} \ldots \\
& p_{m, \max , i}=p_{m d}+p_{m l}
\end{aligned}
$$

である.これは

$$
p_{m, \max , i}=l_{i}^{T} E P \text {. }
$$

のようにマトリックス表示することができる.ここに， $\boldsymbol{P}=\left[\begin{array}{llll}p_{d} & P_{l} & p_{l}\end{array}\right]^{T}$ であり, $\boldsymbol{E}=\left[\begin{array}{lll}\boldsymbol{e}_{1} & \boldsymbol{e}_{2} & \boldsymbol{e}_{3}\end{array}\right]$ とするが，そ の列ベクトル $\boldsymbol{e}_{i}(i=1,2,3)$ は, 次のように求められ る.

(1) $e_{1}$ は，式 $(17 \cdot a) ，(18) よ り$ 注6)

$$
l_{i}{ }^{T} e_{1}=\left(S_{+}-S_{-}\right)
$$

となるので，おのおのの隣り合う縦距で囲まれた台形の 面積を求めればよい. 図一2 の各パネルの長さを $d_{i}, i=$ $1,2, \cdots, s$ とすると， $e_{1}$ は次のように定められる.

$$
\boldsymbol{e}_{1}=\left[\frac{d_{1}+d_{2}}{2} \frac{d_{2}+d_{3}}{2} \cdots \frac{d_{s-1}+d_{s}}{2}\right]^{T}
$$

(2) $e_{2}$ は; 式 $(17 \cdot \mathrm{b}),(18)$ より

$l_{i}{ }^{T} e_{2}=l_{\max }$ 
でなければならないので, $l_{\mathrm{max}}$ がベクトル $l_{i}$ の第 $k$ 番 目の值であるならば,

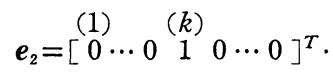

とすればよい。

(3) $e_{3}$ は, 式 $(17 \cdot b),(18)$ より

$$
\boldsymbol{l}_{i}^{T} \boldsymbol{e}_{3}=S \text {. }
$$

としなければならない. つまり， $S_{+}$か $S_{-}$の一方のみ を求めることになる. ただし， ワーレントラスの上下弦 材のように, 縦距の符号がすべて同じ場合は, $S_{+}$か $S_{-}$ のどちらか一方は0であるので, $e_{3}=e_{1}$ でよい. 隣り合 う縦距の符号が 1 か所以上異なっている 場合は, 図一2 に示すように, 符号の変化する所では台形でなく，2つ の三角形のうちの一方の面積を求めることになるため, 次に定義する $q$ を補正量として面積を求める.

$$
q(k, k+1)=\frac{\left|l_{k}\right|}{\left|l_{k}\right|+\left|l_{k+1}\right|}
$$

したがって，たとえば，図一2 において $S_{-}$の面積を求 める場合に用いる $e_{3}$ は,

$$
\boldsymbol{e}_{3}=\left[\begin{array}{ll}
\frac{d_{1}+d_{2} \cdot q(1,2)}{2} & 0
\end{array}\right]^{T}
$$

となる. 以上より, $\boldsymbol{E}$ が求まるので, 式 (18) より得ら れた $p_{m, \max , i}$ を第 $i$ 番目の要素とする最大部材断面力 ベクトルを $\boldsymbol{p}_{\boldsymbol{m}, \max }$ とし, 最大応力を $\boldsymbol{\sigma}_{\max }$ として次 式が得られる.

$$
\boldsymbol{\sigma}_{\max }=\boldsymbol{D}_{m} \boldsymbol{p}_{m, \max }
$$

\section{（2）影響線マトリックスを用いた最適設計}

活荷重の作用する骨組構造の最適設計において, 忘力 や変位の制約条件は, 影響線を描いて各断面の最大応力 や変位を生ぜしめるような荷重配置に対して成立する必 要がある. 静定骨組構造で, 設計変数として断面特性值 のみを用いるときは, 影響線は設計変数に関係なく一定 であるから，最適設計の計算に最大応力や変位を与える ような荷重配置を決めることが可能であり，従来このよ うな操作による最適設計の研究は行われている.

ここでは, 静定構造であっても, 構造が複雑で影響線 の作図が困難であって，しかも節点座標を設計変数とす る場合, また, 不静定構造で, 影響線そのものが設計変 数の関数となり, あらかじめ荷重配置を設定することが できない場合を対象にして，既述の影響線マトリックス を用いた最適設計における感度係数の誘導を試みる.

式 (26) と式 (18) における応力 $\boldsymbol{\sigma}_{\max }$ および部材断面 力 $\boldsymbol{p}_{m, \max }$ の要素 $p_{m, \max , i}$ の設計变数 $X$ についての 導関数は,

$$
\frac{\partial \boldsymbol{\sigma}_{\max }}{\partial X}=\frac{\partial \boldsymbol{D}_{m}}{\partial X} \cdot \boldsymbol{p}_{m, \max }+\boldsymbol{D}_{m} \frac{\partial \boldsymbol{p}_{m, \max }}{\partial X}
$$

および

$$
\frac{\partial p_{m, \max , i}}{\partial X}=\frac{\partial \boldsymbol{l}_{i}^{T}}{\partial X} \boldsymbol{E P}+\boldsymbol{l}_{i}^{T} \frac{\partial \boldsymbol{E}}{\partial X} \boldsymbol{P}
$$

である. 縦距 $l_{i}$ は式 (16) の $\boldsymbol{\Gamma}$ マトリックスから直接 求められるので, 上式の $\partial l_{i}^{T} / \partial X$ は次式から得られる.

$$
\begin{aligned}
\frac{\partial \boldsymbol{\Gamma}}{\partial X}= & \frac{\partial \boldsymbol{K}_{m}}{\partial X} \boldsymbol{C}^{T} \boldsymbol{G}^{-1}+\boldsymbol{K}_{m} \frac{\partial \boldsymbol{C}^{\boldsymbol{T}}}{\partial X} \boldsymbol{G}^{-1} \\
& +\boldsymbol{K}_{m} \boldsymbol{C}^{T} \frac{\partial \boldsymbol{G}^{-1}}{\partial X} \cdots \ldots \ldots \ldots \ldots \ldots
\end{aligned}
$$

また, 式（28）において

$$
\frac{\partial \boldsymbol{E}}{\partial X}=\sum_{k=1}^{s-1} \frac{\partial \boldsymbol{E}}{\partial l_{k}} \frac{\partial l_{k}}{\partial X}
$$

である. ここで, マトリックス $\boldsymbol{E}$ においいて, $l_{\boldsymbol{k}}$ に依存 するのは式 (24) で定義される $q(k, k+1)$ のみである ことに留意すれば $\partial \boldsymbol{E} / \partial l_{k}$ は容易に求められる.

$X$ が断面特性值のみからなる場合は, 不静定構造で あっても，接続マトリックスを構成する $\boldsymbol{T}$ および $\boldsymbol{H}$ は $X$ には無関係であるから $\partial C / \partial X=0$ となる. また, 静 定構造では $\partial \boldsymbol{p}_{m, \max } / \partial X=0$ である.

\section{4. 適用 例}

上記の理論を用いて, 骨組形状の最適設計と影響線を 用いたトラス橋の最適設計の解析例について述べる. 制 約条件は道路橋示方書 ${ }^{22)}$ に従うものとするが, 剛結合部 材の圧縮許容応力度は, 感度係数の算出が繁雑になるの で, 本適用例においては定数 (SS 41 では $-1400 \mathrm{~kg} /$ $\mathrm{cm}^{2}$ ) として解析した. 採用した制約条件式は，次のと おりである。

(1) 応力制限 $\boldsymbol{\sigma}_{a c}(\lambda) \leqq \boldsymbol{\sigma}_{m} \leqq \boldsymbol{\sigma}_{\boldsymbol{a t}}$.

(2) 細長比制限 $\lambda_{L} \leqq \lambda \leqq 120$ or 200 .

(3) 板厚制限 $t_{w}$ and $t_{f} \geqq 0.8 \mathrm{~cm}$.

(4) たわみ制限 $d_{s} \leqq L_{s} / 600$

ここに, $\sigma_{m}$ は実応力度, $\sigma_{a t}$ は許容引張応力度, $\sigma_{a c}(\lambda)$ は許容圧縮応力度で, 細長比入の関数となる. また, $\lambda_{L}$ は細長比の下限で, 面外座屈防止の条件 $I_{y}>I_{x}$ より求 められる. $d_{s}$ は節点のたわみの最大值, $L_{s}$ はスパン長 である. 目的関数は, 主構体積 $z$ で, これを最小とす る.すなわち, 次式のとおりである.

$$
z=\sum_{i=1}^{k} A_{i} L_{i} \rightarrow \min
$$

\section{(1) 6 パネルトラス}

6 パネルトラスについて, 骨組形状の最適設計を行 う. スパン長 $50.4 \mathrm{~m}$ 使用鋼種 SS 41 の場合について, 次の 3 ケースの解析を行う.

[ケース 1]

制約条件：式 (31)， 


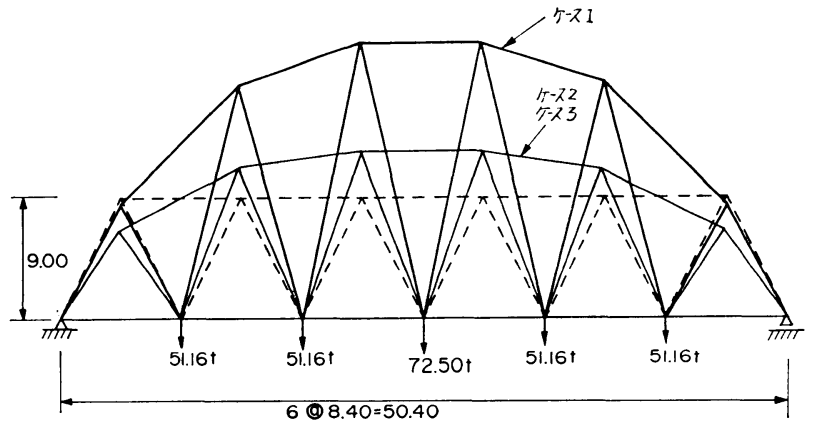

図一36パネルトラスの最適骨組形状

単位: $\mathrm{m}$

$1 \mathrm{t}=9.8 \mathrm{kN}$

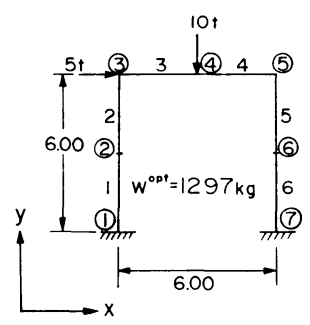

（a）ケース1（初期形状）

図一4 門型ラーメンの罗適骨組形状

設計変数 : 断面積 $A$, 細長比 $\lambda$, 上弦材の $y$ 方向節点 座標

[ケース 2]

制約条件：式 (31) (34)

設計変数 : ケース 1 に無次元パラメーター $C_{F}$ と部材 幅 $b$ （全部材で 1 つの変数）を追加.

\section{[ケース 3$]$}

剛結構造として, 曲げモーメントを考虑した解析で, 設計変数，制約条件はケース 2 と同じ．ただし，圧縮部 材の許容応力度は $\sigma_{a c}=-1400 \mathrm{~kg} / \mathrm{cm}^{2}(-137 \mathrm{MPa})$ と する.

図一3 は，モデルの載荷条件と各ケースについて行っ た解析結果を示したが，ケース 2 とケース 3 の骨組形状 の最適值はほぼ一致した. 骨組形状の初期値は, 図中点 線で示す主構高 $9 \mathrm{~m}$ のワーレントラスとした. ケース 1 の最適解では，斜材はすべて引張であり，いわば吊材と して機能しているためトラス構造とはいえないものであ る. ケース 2,3 は, ともに曲弦トラスであり, 最終的 な骨組形状が，ほぼ一致したのは，このような骨組形状 自体が軸力の卓越する構造であるので, 曲げモーメント の効果が僅少となるうえ，大半の部材が 板厚制限のた め，座標值の動きがおさえられているためと思われる.

以上のことから，骨組形状も含めた最適設計を行う場 合には, 設計変数あるいは制約条件が変化すると解析結 果はかなり大きな違いが出てくることがわかる．また， 断面の特性值としては，断面積Aのみを設計変数にする ときと, $A$ 以外に細長比, 部材幅, 無次元パラメーター
$C_{F}$ 等を用いるときでは 結果がかなり相違するか ら, 設計変数の選択には注意を払う必要がある. さらに，制約条件として板厚の制限等も加えるべ きである.

\section{(2) 門型ラーメン}

剛結構造の骨組形状の最適設計の例として, 図 一4に門型ラーメンの解析例を示す. 制約条件は 式 (31) (33) で, 許容応力度は $\sigma_{a}= \pm 1400 \mathrm{~kg} /$ $\mathrm{cm}^{2}( \pm 137 \mathrm{MPa})$ とした. 荷重は, 節点 3 の $x$ 方 向に $5 \mathrm{t}(49 \mathrm{kN})$, 節点 4 の $y$ 方向に $-10 \mathrm{t}(-98$ $\mathrm{kN})$ をかける. ケース 1 は，骨組形状を固定した 場合で，設計変数は 19 個である. ケース 2 は, 節点 5 の $(x, y)$ 座標を設計変数として追加した 場合であり，ケース 3 は，節点 5 と 6 の $(x, y)$ 座標を設計変数として追加した場合で, 設計変数 は 23 個である. 初期の骨組形状はケース 1 亿等 しい.

表一1 は，3 ケースについて, 初期值と最適值 を示したものである. なお，ムーブリミットは断

表一1 門型ラーメンの初期值と最適値

\begin{tabular}{|c|c|c|c|c|c|}
\hline & & \multirow{2}{*}{ 初 期 值 } & \multicolumn{2}{|l|}{ 最 } & 值 \\
\hline & & & ケース 1 & ケース 2 & ケース 3 \\
\hline \multicolumn{2}{|c|}{ 重 量 $W(\mathrm{~kg})$} & 7065 & 1297 & 852 & 685 \\
\hline \multicolumn{2}{|c|}{ 部材幅 $b(\mathrm{~cm})$} & 30.0 & 29.1 & 20.2 & 16.8 \\
\hline \multirow{6}{*}{$\begin{array}{c}\text { 断 面 積 } \\
A \\
\left(\mathrm{~cm}^{2}\right)\end{array}$} & 1 & 500.0 & 94.1 & 54.1 & 41.2 \\
\hline & 2 & 500.0 & 76.7 & 50.0 & 47.5 \\
\hline & 3 & 500.0 & 94.1 & 56.4 & 48.9 \\
\hline & 4 & 500.0 & 94.1 & 58.2 & 76.8 \\
\hline & 5 & 500.0 & 102.8 & 66.4 & 59.7 \\
\hline & 6 & 500.0 & 87.6 & 112.6 & 67.0 \\
\hline \multirow{6}{*}{$\begin{array}{c}\text { ウ 至 ブ } \\
\text { 板 厚 } \\
t_{w} \\
(\mathrm{~cm})\end{array}$} & 1 & 4.23 & 0.80 & 0.80 & 0.80 \\
\hline & 2 & 4.23 & 0.80 & 0.80 & 0.80 \\
\hline & 3 & 4.23 & 0.80 & 0.80 & 0.80 \\
\hline & 4 & 4.23 & 0.80 & 0.80 & 1.22 \\
\hline & 5 & 4.23 & 1.08 & 0.88 & 1.03 \\
\hline & 6 & 4.23 & 0.80 & 1.88 & 0.80 \\
\hline \multirow{6}{*}{$\begin{array}{c}\text { フランシ } \\
\text { の 板 厚 } \\
t_{f} \\
(\mathrm{~cm})\end{array}$} & 1 & 13.45 & 0.80 & 0.80 & 0.80 \\
\hline & 2 & 13.45 & 0.80 & 0.80 & 0.80 \\
\hline & 3 & 13.45 & 0.80 & 0.80 & 0.80 \\
\hline & 4 & 13.34 & 0.80 & 0.83 & 1.42 \\
\hline & 5 & 13.45 & 0.80 & 0.80 & 0.81 \\
\hline & 6 & 13.45 & 0.80 & 1.80 & 1.10 \\
\hline \multirow{2}{*}{$x(\mathrm{~m})$} & 5 & 6.00 & $6.00^{*}$ & 4.60 & 4.45 \\
\hline & 6 & 6.00 & $6.00^{*}$ & $6.00^{*}$ & 4.45 \\
\hline \multirow{2}{*}{$y(\mathrm{~m})$} & 5 & 6.00 & $6.00^{*}$ & 4.73 & 5.35 \\
\hline & 6 & 3.00 & $3.00^{*}$ & $3.00^{*}$ & 2.01 \\
\hline \multirow{6}{*}{$\begin{array}{c}\text { 実応力度 } \\
\sigma \\
\left(\mathrm{kg} / \mathrm{cm}^{2}\right)\end{array}$} & 1 & -499.5 & -955.7 & -143.2 & 92.3 \\
\hline & 2 & -174.9 & $-\quad 534.5$ & -422.3 & 79.2 \\
\hline & 3 & -645.9 & -1156.1 & -1399.2 & -974.4 \\
\hline & 4 & -834.9 & -1398.7 & -1399.4 & -1216.3 \\
\hline & 5 & -830.7 & -1397.3 & -1400.3 & -1260.3 \\
\hline & 6 & -753.4 & -1399.6 & -1398.3 & -1320.0 \\
\hline
\end{tabular}

注：*は定数とする

$1 \mathrm{~kg}=9.8 \mathrm{~N}, 1 \mathrm{~kg} / \mathrm{cm}^{2}=0.098 \mathrm{MPa}$ 


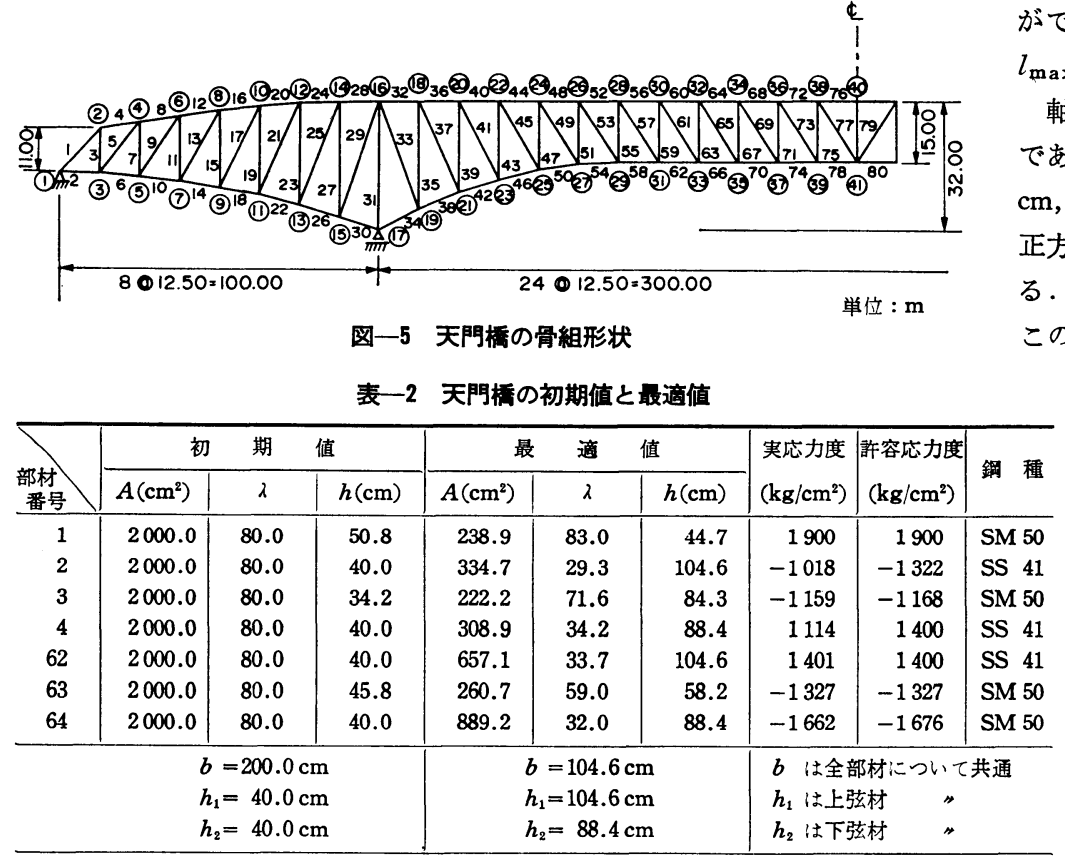

注 $: 1 \mathrm{~kg} / \mathrm{cm}^{2}=0.098 \mathrm{MPa}$

面特性值については，はじめ 0.3 とし，制約条件に近づ くごとに, 小さくするものとし，座標については $10 \mathrm{~cm}$ を範囲とした.

接続マトリックスを用いると，本例題のような剛結合 構造において節点座標と断面形状に関して，それぞれ複 数の種類の設計変数のある最適設計問題においても感度 係数の誘導が解析的に簡潔に行える.

\section{（3）天 門 橋 ${ }^{23}$}

図一5 に示寸天門橋（天草一号橋）と同じ骨組形状の モデルで，移動荷重を考虑した部材最大断面力について 制約条件式をたてて最適設計を行う。設計変数は，断面 積 $A$, 細長比 $\lambda$ を各部材ごとの変数とし, 部材幅 $b$ は 全部材共通，部材高 $h$ は上下弦材でそれぞれ共通 (こ れを $h_{1}, h_{2}$ とする) 斜材, 垂直材は 各部材独立の変数 とする. 断面形状は, 部材番号 69 と 73 の斜材のみ I 型 とし，その他は箱型とした．鋼種は，部材によって SS 41, SM 50, SM 58 のいずれかを使用する. たとえば, 下弦材の部材番号 $54,58,62$ は SS 41, 上弦材の部材 番号 12，16，20，24 等は SM58 とした. 制約条件は 式 (31)〜(34) である.

骨組形状の対称性を考慮して, 部材数は 79 , 設計変数 は201である．また，式（18）における設計荷重は， $p_{d}$ $=45.98 \mathrm{~kg} / \mathrm{cm}(45.1 \mathrm{kN} / \mathrm{m}), P_{l}=1568 \mathrm{~kg}(15.4 \mathrm{kN})$, $p_{l}=9.41 \mathrm{~kg} / \mathrm{cm}(9.2 \mathrm{kN} / \mathrm{m})$ とした. 表一2 は, 初期値 と最適值の一部を, 図一6 は最適解における影響線図の 一部を示したものでありここれは自動的に作図すること
ができる. 図中の数值は，各部材の $l_{\max }$ の值である.

軸力が最大となるのは第 34 部材 であったが，最適解は $b=h=104.6$ $\mathrm{cm}, t_{f}=t_{w}=1.8 \mathrm{~cm}$ で, いわゆる 正方形等厚の箱型部材 となってい る.1 部材のみの最適設計を行えば， この形状が 解であることがわかる。 また，全部材の $80 \%$ にあた る 63 部材が許容応力度いっ ぱいの断面になっているが, その他は，板厚 制限や部材 幅，部材高によって断面が決 定される.つまり, 設計変数 の一部をグループごとに共通 な変数にするという実橋の設 計に即した条件を考慮してい くと全応力設計にはならな い. 本例題のように実橋の骨 組形状を与えた場合において も影響線解析はマトリックス演算のみで処理され，部材 最大断面力, 最大変位およびそれらの感度係数の算出は きわめて容易に行うことができる.

\section{5. 結論}

（1）接続マトリックスが座標変換マトリックス $\boldsymbol{T}$ と 平衡マトリックス $\boldsymbol{H}$ によって組み立てられることに着 目して, これら $\boldsymbol{T}$ と $\boldsymbol{H}$ のマトリックスを用いると最 適設計における感度係数の誘導がより簡潔かつ組織的に 行えること，したがって，剛結骨組構造の座標を設計変 数とするような繁雑な最適形状設計の定式化が 比較的容

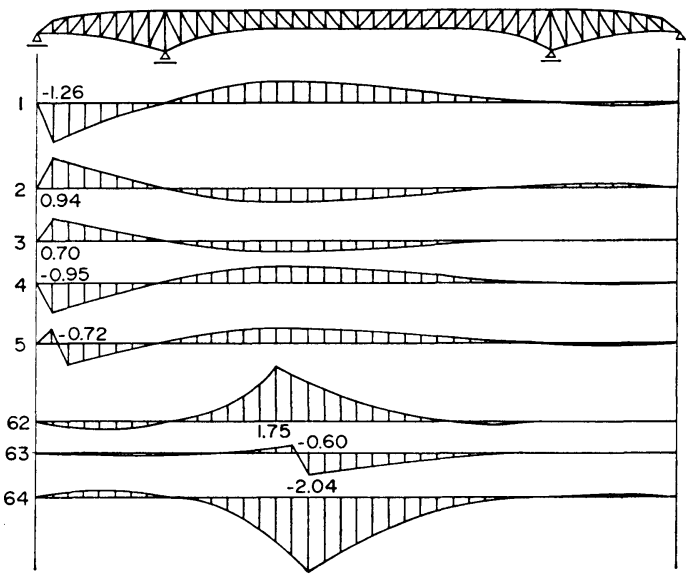

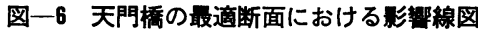


易になることを指摘した. また，その例題として，6パ ネルトラスおよび門型ラーメンの計算例を示した.

（2）骨組鋼構造において，もっぱら用いられる箱型 とか I 型の断面形状を示す設計変数として, ウェブおよ びフランジの板厚の代わりに断面積と細長比を用い, こ れに部材の高さと部材幅を加えた 4 個の独立パラメータ 一を設計変数とすると最適設計の定式化が容易になるこ とを指摘した.これは，座屈条件式，目的関数等が上記 のパラメーターの関数となっているためである. 部材高 $h$ の代わりに最小回転半径を $r$ として $C_{F}=h / 2 r$ とい う無次元パラメーターを用いることも可能である. 例題 として，6 パネルトラスの最適設計を試みたが， 単に断 面積のみを設計変数とするよりは，上記 4 個のパラメー ターを用いる方が，より現実的な最適形状が誘導される ことを述べた。

（3）接続マトリックスを用いると，骨組構造に活荷 重が作用するときの最大断面力や変位を与える影響線 トリックスの誘導が, 静定, 不静定にかかわらず容易と なる. 例題として, 3 径間連続トラスの天草天門橋の影 響線を自動的に描いた。

（4）活荷重の作用する場合，不静定構造で，断面力 や変位の影響線そのものが 設計変数の関数となる場合 や，静定であっても構造が複雑で影響線の作図が困難で あったり，また，座標を設計変数とする場合には，前項 の影響線マトリックスを用いると最適設計における感度 係数の誘導が直接剛性法を用いるよりも容易なることを 述べ，天草天門橋の最適設計を行った。

謝 辞 : 本研究の一部は, 著者らの指導による杉野 朗君（現在熊本大学工学部大学院工学研究科）の熊本大 学工学部卒業研究の主題となっている. 図面の作製にあ たっては, 熊本大学工学部技官 松本英敏氏のご協力を 得た. 使用した計算機は, 九州大学大型計算機センター の FACOM M-200 である. 関係各位に謝意を表する.

\section{補戔}

(1) $K_{m}$ および $D_{m}$ について

式（8）に示された $\boldsymbol{K}_{i}$ は, 部材 $i$ の 1 端を固定した ときの 2 端の断面力 $\boldsymbol{p}_{i 2}$ とそれに基づく変形べクトル $\boldsymbol{e}_{i_{2}}$ の関係を規定する 剛性マトリックスで, $\boldsymbol{p}_{i_{2}}=\boldsymbol{K}_{\boldsymbol{i}} \boldsymbol{e}_{i_{2}}$ であり，式（9）に示された $\boldsymbol{D}_{i}$ は， $\boldsymbol{p}_{i 2}$ を 2 端の応力 $\sigma_{i 2}$ に変換する係数 マトリックスで $\sigma_{i 2}=D_{i 2} p_{i 2}$ とな る.これより $K_{m}, D_{m}$ と $K_{i}, D_{i}$ の関係は,

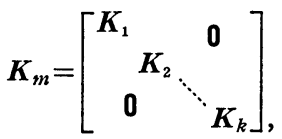

$$
\sigma_{m}=\left[\begin{array}{c}
\sigma_{12} \\
\sigma_{22} \\
\vdots \\
\sigma_{k 2}
\end{array}\right]=\left[\begin{array}{cccc}
D_{1} & & & 0 \\
& D_{2} & & \\
0 & \ddots & \\
& & & D_{k}
\end{array}\right]\left[\begin{array}{c}
p_{12} \\
p_{22} \\
\vdots \\
p_{k 2}
\end{array}\right]=D_{m} p_{m}
$$

となる.

(2) $\boldsymbol{T}_{i}, \boldsymbol{H}_{i}$ について

各部材の平衡マトリックス $\boldsymbol{H}_{i}$ と座標変換マトリック ス $\boldsymbol{T}_{i}$ は

$$
\boldsymbol{H}_{i}=\left[\begin{array}{ccc}
\gamma & -\mu & 0 \\
\mu & \gamma & 0 \\
0 & 0 & 1
\end{array}\right]_{i}, \quad \boldsymbol{T}_{i}=\left[\begin{array}{lll}
1 & 0 & 0 \\
0 & 1 & 0 \\
0 & L & 1
\end{array}\right]_{i}
$$

である。

(3) $\partial L_{i} / \partial x_{j}, \partial r_{i} / \partial x_{j}, \partial \mu_{i} / \partial x_{j}$ について

部材 $i$ の 1 端および 2 端の座標を $\left(x_{i 1}, y_{i 1}\right),\left(x_{i 2}\right.$, $y_{i 2}$ ) とすると

$$
\begin{aligned}
& L_{i}=\sqrt{\left(x_{i 2}-x_{i 1}\right)^{2}+\left(y_{i 2}-y_{i 1}\right)^{2}} . \\
& r_{i}=\left(x_{i 2}-x_{i 1}\right) / L_{i} \ldots \ldots \ldots \ldots \ldots \ldots \ldots \ldots \ldots \ldots \ldots \ldots \ldots \ldots \ldots \ldots \ldots \ldots \ldots \ldots \ldots
\end{aligned}
$$

となる. したがって, $\partial L_{i} / \partial x_{j}$ は

$$
\frac{\partial L_{i}}{\partial x_{i 1}}=-\gamma_{i}, \frac{\partial L_{i}}{\partial x_{i 2}}=\gamma_{i}, \frac{\partial L_{i}}{\partial y_{i 1}}=-\mu_{i}, \frac{\partial L_{i}}{\partial y_{i 2}}=\mu_{i}
$$

となる. また, $\partial r_{i} / \partial x_{j}, \partial \mu_{i} / \partial x_{j}$ は

$$
\begin{aligned}
& \frac{\partial r_{i}}{\partial x_{i 1}}=-\frac{\mu_{i}^{2}}{L_{i}}, \frac{\partial r_{i}}{\partial x_{i 2}}=\frac{\mu_{i}^{2}}{L_{i}}, \frac{\partial r_{i}}{\partial y_{i_{1}}}=\frac{r_{i} \mu_{i}}{L_{i}}, \\
& \frac{\partial r_{i}}{\partial y_{i 2}}=-\frac{r_{i} \mu_{i}}{L_{i}} \cdots \cdots \cdots \cdots \cdots \cdots \cdots \cdots \cdots \cdots \cdots(\mathrm{A} \cdot 7) \\
& \frac{\partial \mu_{i}}{\partial x_{i 1}}=\frac{r_{i} \mu_{i}}{L_{i}}, \frac{\partial \mu_{i}}{\partial x_{i 2}}=-\frac{r_{i} \mu_{i}}{L_{i}}, \frac{\partial \mu_{i}}{\partial y_{i 1}}=-\frac{r_{i}{ }^{2}}{L_{i}}, \\
& \frac{\partial \mu_{i}}{\partial y_{i 2}}=\frac{r_{i}^{2}}{L_{i}} \ldots \ldots \ldots \ldots \ldots \ldots \ldots \ldots \ldots \cdots \cdots(\mathrm{A} \cdot 8)
\end{aligned}
$$

(4) $e_{1}$ ベクトルについて

図一2 のトラスを例にとって $e_{1}$ ベクトルの意味を明 らかにする．縦距がすべて同符号の場合には，

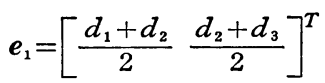

となる. しかし, 縦距の符号が異なる場合には, 式 (24) で定義した補正量 $q$ をかけて

$$
\boldsymbol{e}{ }^{\prime}=\left[\begin{array}{ll}
\frac{d_{1}+d_{2} \cdot q(1,2)}{2} & \frac{d_{2} \cdot q(2,1)+d_{3}}{2}
\end{array}\right]^{T}
$$

が厳密な值である. ところが, 式 (19) で示した $S_{+}-S_{-}$ を求めるためには $l_{i}^{T} e_{1}$ でも $l_{i}{ }^{T} e_{1}{ }^{\prime}$ でも同じことにな る. 以下に, この等式 $l_{i}{ }^{T} e_{1}=l_{i}{ }^{T} e_{1}{ }^{\prime}$ を導く. まず, 図 -2より

$$
S_{-}=\frac{\left|l_{1}\right| d_{1}}{2}+\frac{\left|l_{1}\right| d_{2} \cdot q(1,2)}{2},
$$




$$
S_{+}=\frac{\left|l_{2}\right| d_{2} \cdot q(2,1)}{2}+\frac{\left|l_{2}\right| d_{3}}{2}
$$

よって, $\boldsymbol{l}_{i}^{T}=\left[\begin{array}{ll}l_{1} & l_{2}\end{array}\right]$ とすると

$$
\begin{gathered}
S_{+}-S_{-}=\frac{l_{1} d_{1}}{2}+\frac{l_{1} d_{2} \cdot q(1,2)}{2}+\frac{l_{2} d_{2} \cdot q(2,1)}{2} \\
+\frac{l_{2} d_{3}}{2}=\left[\begin{array}{ll}
l_{1} & l_{2}
\end{array}\right]\left[\begin{array}{l}
\frac{d_{1}+d_{2} \cdot q(1,2)}{2} \\
\frac{d_{2} \cdot q(2,1)+d_{3}}{2}
\end{array}\right]
\end{gathered}
$$

となる. 次に $\boldsymbol{l}_{i}^{T} \boldsymbol{e}_{1}$ を求めると

$$
\begin{aligned}
& \boldsymbol{l}_{i}^{T} \boldsymbol{e}_{1}=\left[\begin{array}{ll}
l_{1} & l_{2}
\end{array}\right]\left[\begin{array}{l}
\frac{d_{1}+d_{2}}{2} \\
\frac{d_{2}+d_{3}}{2}
\end{array}\right]=\frac{l_{1} d_{1}}{2}+\frac{l_{1} d_{2}}{2}+\frac{l_{2} d_{2}}{2}+\frac{l_{2} d_{3}}{2} \\
& =\frac{l_{1} d_{1}}{2}+\frac{l_{1} d_{2}}{2}\left(\frac{\left|l_{1}\right|}{\left|l_{1}\right|+\left|l_{2}\right|}\right)+\frac{l_{1} d_{2}}{2}\left(\frac{\left|l_{2}\right|}{\left|l_{1}\right|+\left|l_{2}\right|}\right) \\
& +\frac{l_{2} d_{2}}{2}\left(\frac{\left|l_{2}\right|}{\left|l_{1}\right|+\left|l_{2}\right|}\right)+\frac{l_{2} d_{2}}{2}\left(\frac{\left|l_{1}\right|}{\left|l_{1}\right|+\left|l_{2}\right|}\right)+\frac{l_{2} d_{3}}{2} \\
& =\frac{l_{1} d_{1}}{2}+\frac{l_{1} d_{2} \cdot q(1,2)}{2}+\frac{l_{2} d_{2} \cdot q(2,1)}{2} \\
& +\frac{l_{2} d_{3}}{2}+\left\{\frac{d_{2}}{2}\left(\frac{l_{1}\left|l_{2}\right|+l_{2}\left|l_{1}\right|}{\left|l_{1}\right|+\left|l_{2}\right|}\right)\right\} \\
& =\boldsymbol{l}_{\boldsymbol{i}}{ }^{T} \boldsymbol{e}_{1}{ }^{\prime}=S_{+}-S_{-}
\end{aligned}
$$

となる. 上式において \{ \} の中は $l_{1}$ と $l_{2}$ が常に異符 号であるので恒等的にゼロである.つまり, 式 (19) に おいて $S_{+}-S_{-}$を求めるには，常に $\boldsymbol{l}_{i}{ }^{T} \boldsymbol{e}_{1}$ でよいこと になる. したがって, $e_{2}, e_{3}$ を求める際には, $l_{i}^{T} e_{1}$ の 符号さえわかれば， あとは，機械的に求められる.

\section{参 考 文 献}

1) Schmit, L.A. and T.P. Kircher : Synthesis of Material and Configuration Selection, Proc. of ASCE, Vol. 88, ST. 3, pp. 79 102, June, 1962.

2) Spillers, W.R. and G.E. Kountouris : Geometric Optimization Using Simple Code Representation, Proc. of ASCE, Vol. 106, ST. 5, pp. 959 971, May, 1980.

3) Lipson, S.L. and M.I. Haque : Optimal Design of Arches Using the Complex Method, Proc. of ASCE, Vol. 106, ST. 12, pp. 2509 2525, December, 1980.

4）大久保禎二：トラス構造物の最適設計法に関する研究, 土 木学会論文報告集, 第 177 号, pp. 9 19, 1970 年 5 月.

5）杉本博之：トラス構造物の実用的最適設計に関する研究, 土木学会論文報告集, 第 208 号, pp. 23 31, 1972 年 12 月.
6) 小山 健・長 尚：最適設計における計算の効率に関す る研究, 土木学会論文報告集, 第 297 号, pp. 1 9, 1980 年 5 月.

7) Vanderplaats, G.N. and F. Moses : Automated Design of Trusses for Optimum Geometry, Proc. of ASCE, Vol. 98, ST. 3, pp. 671 690, March, 1972.

8) Kirsch, U. and F. Moses : Decomposition in Optimum Structural Design, Proc. of ASCE, Vol. 105, ST. 1, pp. 85 99, January, 1979.

9）奥村敏恵・大久保禎二：Suboptimization による 鋼連続 妳の最適設計, 土木学会論文報告集, 第 215 号, pp. 1 14,1973 年 7 月.

10）前掲 1) pp. $82 \sim 99$.

11) Dobbs, M.W. and L.P. Felton : Optimization of Truss Geometry, Proc. of ASCE, Vol. 95, ST. 10, pp. 2105 $\sim 2118$, October, 1969.

12) Pederson, $\mathrm{P}:$ Optimal Joint Positions for Space Trusses, Proc. of ASCE, Vol. 99, ST. 12, pp. 2459 2477, December, 1973.

13) Saka, M.P. : Shape Optimization of Trusses, Proc. of ASCE, Vol. 106, ST. 5, pp. 1155 1174, May, 1980.

14) Imai, K. and L.A. Schmit : Configuration Optimization of Trusses, Proc. of ASCE, Vol. 107, ST. 5, pp. 745 756, May, 1981.

15）中村雄治：最適設計・コンピューター使用によるマトリ ックス構造解析, 日本鋼構造協会講習会テキスト, pp. 132 158, 1968 年 11 月.

16) Furuta, H. : Fundamental Study on Geometrical Configuration and Reliability of Framed Structures used for Bridges, Dept. of Civil Eng. Kyoto Univ., pp. 1 $\sim 90,1980$.

17) Romstad, K.M. and C. Wang : Optimum Design of Framed Structures, Proc. of ASCE, Vol. 94, ST. 12, pp. 2817 2845, December, 1968.

18) Livesley, R.K. : Matrix Methods of Structural Analysis, Pergamom Press, pp. 117 134, 1969.

19）吉本俊裕・三池亮次：接続マトリックスによる剛結を考 虑した骨組構造物の最適設計, 熊本大学工学部研究報告, 第 25 巻, 第 2 号, pp. 1 10, 1976 年 7 月.

20）小林一郎・三池亮次：接続マトリックスの最適設計への 応用一影響線を考虑したトラスの最適設計, 熊本大学工 学部研究報告, 第 31 巻, 第 1 号, pp. 1 10, 1982 年 3 月.

21）三池亮次・小林一郎：無次元数を用いた最適設計, 土木 学会第 33 回年次学術講演会講演概要集, 第 1 部門, pp. $252 \sim 253,1978$ 年 9 月.

22）道路橋示方書・同解説，I 共通編，II 鋼橋編，日本道路協 会, 1980 年 2 月.

23）工事報告・天草五橋, 日本道路公団, pp. $63 \sim 89,1967$ 年 5 月.

(1982.8.24 ·受付) 